\title{
Ruin and organization studies
}

\author{
Christian De Cock \\ University of Essex, UK
}

\&

Damian O'Doherty

University of Manchester, UK

Corresponding author: Christian De Cock, Essex Business School, University of Essex, Wivenhoe Park, Colchester CO4 3SQ, UK. Email: cdc@essex.ac.uk 


\title{
Ruin and organization studies
}

\begin{abstract}
In this paper we offer a preliminary study of the various ways in which 'ruin' has significance for organization studies. One important motif associated with both modern and romantic treatments of the ruin is the revelatory impressions ruins make. In this respect the traditions of ruin writing will talk of their 'beauty', their 'strangeness' or their capacity to 'intimidate'. In order to attend to this elusive phenomenon we must necessarily breach some of the self-imposed boundaries of our 'discipline'. Central to our strategy is the use of 'contiguity' as both method and textual structuring device that allows us to drift across iconic ruin images, ruin theories, and our own ruinous research experiences. This helps us learn how to 'dwell' in ruins without any impatient reaching after fact or explaining away ruins in the terms of any established tradition of theorizing in organization. In this way we hope to be able to open up new analytic spaces and associations for organizational researchers. These concern specifically a) a distinctive approach to time, history and memory; b) an increased awareness of the multiplicity of forces impinging on organization, but from which we so easily retreat behind the cordon sanitaire of organization-studies-as-usual; and c) a cognizance of how the very way we write is a mode of doing organization that is crucial for our ability and willingness to look into 'all corners of reality' so that we might better grasp organizational phenomena.
\end{abstract}

Keywords: Benjamin, catastrophe, ethnography, history, memory, spatiality, Ruin, Sebald 


\section{Ruin and organization studies}

\section{Introduction: fragmented beginnings}

Ruin is all around us. So where better to begin writing about ruin and organization studies than with a glance at our own mantelpiece upon which sits a small piece of concrete that was once a part of the Berlin Wall, the remains of which are probably "the most iconic ruin of the late $20^{\text {th }}$ century", and "whose destruction was hailed as the end of history..." (Hell \& Schőnle, 2010, p.3). It is contained in a tacky plastic box with bits of accompanying text stating,

“The Berlin wall... was breached on November 12th $1989^{1}$ [sic], allowing the free movement of the peoples and symbolizing a new era of communication, freedom and peace in Europe".

We go on to read that the piece was,

"removed by members of the fund raising team of the Colchester Branch of the National Federation of Self Employed and Small Businesses Ltd [who]... have been chipping away at the wall of red tape and bureaucracy in Britain since 1974".

\section{Insert figure 1 about here: a piece of Berlin Wall}

This small and rather ugly piece of concrete allows us to begin unpacking the notion of ruin. By working through some particular examples of ruins, ruin gazing and ruination we aim to reveal the significance of 'ruin' for organization studies in its material, imaginary, and allegorical dimensions. Of course, confronting ruin as both noun and verb - as a claim about the state of things and the organizational

\footnotetext{
${ }^{1}$ The fall of the Berlin Wall is usually considered to have happened on the 9th of November 1989 when the DDR government first agreed people could travel and thousands climbed over the Wall into West Berlin. It is the same day as the anniversary of the Night of Pogroms, the so-called Reichskristallnacht.
} 
processes affecting it - does not come naturally to scholars in a field ostensibly constituted to study the processes of making and assembling, of drawing things together, of making coherent, of extending and developing. In the current climate of business school expansion and relentless injunctions to be 'excellent', 'positive' and 'forward looking', it might also seem an awkward career move to propose a study of ruins - other than perhaps how to avoid them. And yet, a preoccupation with ruin is on the rise as is evidenced in this very journal. It is perhaps a little known fact that there have been 39 references to 'ruin' or 'ruins' since the first issue of Organization Studies was published; but what is remarkable is ruin's recent prominence with half of those references appearing over the past five years and coinciding with the aftermath of the global financial crisis and European economic austerity ${ }^{2}$.

For us it is precisely the fact that 'ruin' finds itself at such an awkward angle to what we traditionally understand to be the field and practice of organization studies that makes it valuable and relevant. The topic encourages different forms of thinking, above and beyond the normal formal logic and rationalist cognitivism of social scientific research, and enjoins us to consider a greater role for imagistic thinking, associative thought, and following Deleuze (1986), even a form of cinematic thinking. It allows for an unusual blend of the visual/empirical and the theoretical to provide new analytic spaces and associations that, crucially, involve time, memory and spatiality. Opening up such spaces and associations is particularly important as we find ourselves in a historically strange and unique moment where, according to Jameson (2015, p.128), we are experiencing, "the weakening of our phenomenological experience of past and future, and the reduction of our temporality to the present". Ruins as matter out of place/matter out of time, are important because they evoke "a different kind of

\footnotetext{
${ }^{2}$ In what may appear a somewhat awkward statistical production, we find only 3 references in the first 10 years of the journal, an additional 4 in the 1990s, 11 new references in the 2000s, and then 21 references in the first half of our current decade. This is at least suggestive of a perhaps unconscious increasing preoccupation with ruin in organization studies.
} 
attention to the familiar and strange, to both what is singular and significant, what is intentionally askew and out of place" (Stoler, 2012, p.500). They widen our understanding of what organizational processes have done, do, or might do. As such, a ruin optic - a gaze which is acutely sensitive to ruin - makes us hesitate and reflect on our unarticulated but well-rehearsed convictions and credulities about organization. It challenges our epistemic habits - ways of knowing that are available and easy to think and which are of course steeped in history and historical practices - and it makes us aware that our cherished theories are little more than temporarily settled dispositions (Stoler, 2010).

We do not intend to draw immediate 'lessons' or 'applications' from our ruin gazing but rather, following Sebald's (2004) use of 'contiguity' as a textual structuring device, drift across iconic ruin images, ruin theories and our own ruinous field experiences, while collecting thoughts and impressions along the way which we believe are, or should be, of significance for organizational researchers. As we draw impressions together from disparate spaces and times we aim to elucidate how our organized world is held together in ways that belie the usual assumptions about causality or means-ends rationality upon which so much of management education is built. Learning from Sebald we want to ask: How can ruin be made to speak of organization? Instead of the usual way of proceeding in organization studies, by 'spotting gaps' and building up an argument in a linear way (Sandberg and Alvesson, 2011), we move our text forward by seeking to extract surprising connections and juxtapositions of material. This means we vigilantly allow our own text to be moved sideways ${ }^{3}$. Our essay begins with a survey of recent projects and experiments that have sought to recover the various ways in which ruins are both spoken for and create affects. As the perspectives and examples multiply and the concept of 'ruin' takes

\footnotetext{
${ }^{3}$ This method, if it can be called such, is inspired by Walter Benjamin (2002, N1, 2): "Comparison of other people's attempts to the undertaking of a sea voyage in which the ships are drawn off course by the magnetic North Pole. Discover this North Pole. What for others are deviations are, for me, the data which determine my course. On the differentials of time (which, for others, disturb the main lines of the inquiry), I base my reckoning".
} 
on more and more substance, our essay will then explore the possibilities for participating in different forms of organization-making and intervention that emerge when we find ways of letting-go of the alltoo-human desire to control through linearity and means-ends rationality. Reporting on our efforts to develop forms of empirical intervention and experiment that might grant a greater role to the ruins of organization we then extend the idea of 'ruination' introduced in an important essay by Yael NavaroYashin (2009). We seek to move beyond her predominantly metaphorical use of ruination and, inspired by Blanchot's (1955) Writing of the Disaster, attempt to develop a ruinous form of research/writing that retains the ruins of our own thought following the experience of the proliferating disasters that surround us in contemporary organization.

\section{A meditation on ambivalence}

But let us return to the beginning and our fragment of Berlin Wall. It tells us something of the process through which a decayed object or place comes to be framed as ruin when it is "transformed into a physical trace of the past that expresses its own process of decay" (Roth, 1997, p.xi). The rather amusing intervention of our friends from the Colchester Branch of the National Federation of Self Employed and Small Businesses Ltd. brings home the crucial point that stories always fill in the gaps left by the ruin's material remains; or as Presner (2010, p.215) put it: "ruins have consistently to be ventriloquized". When we are confronted with ruins we always face a material base with a metaphoric overlay. Indeed, there are certain visual codes and significations that differentiate between a piece of rubble - which our bit of concrete would be without its added signification - and the ruin as a well-framed window into the past. We thus cannot but historicize the concept of ruin by examining the different stories that it provokes or enables at different times. Of course this also points to a politics of memory about which critical questions must ask who decides a) what is remembered, and b) how this memory should be 
made apparent. Our concrete fragment further makes us aware of the tension between the ruin, with its absences plainly present, and a possible totality whose presence is felt through those absences. A ruin cannot but be a fragment, but as fragment it is often more loaded with meaning than when it was part of a whole (Dillon, 2011). Precisely through the remoteness that they manifest, fragments can disclose meanings which the original whole might conceal.

One casualty of taking ruins seriously is hubris. Those who were proclaiming the 'end of history' (Fukuyama, 1992) at the time of the fall of the Berlin Wall perhaps might have struck a humbler tone if only they had cared to look what was happening in their own capitalist backyard. By 1989 - Detroit, a place so central to storied American capitalism - counted "tens of thousands of empty lots and more than fifteen thousand abandoned homes; stunning Beaux Arts and modernist buildings were deserted, left to return to nature, their floors and roofs covered by switchgrass" (Grandin, 2013, p.117). If we fastforward 25 years the 'irresistible decay' of the bankrupt city of Detroit has become the object of what some have called ruin porn: "a tourist delight, orchestrated participation in the adventure of imagining another time without having to imagine what political processes displaced those who lived in them" (Stoler, 2013, p.32).

A recent Financial Times article provided another example of ventriloquizing ruins in this context, with Tett (2015) praising the Detroit Blight Removal Task Force Plan, produced by a public-private coalition, for its fight against blight and ruination by "openly measuring all the rot in a region". Murray $(2015$, p.6) attacked the role of ruin porn in the Task Force Plan, discussing in detail how the public's gaze was lured away from legal and social problems "toward mesmerizing scenes that speak to Detroiters' greatest

\footnotetext{
${ }^{4}$ One cannot avoid drawing parallels here with Karl Kraus's famous essay Promotional Trips to Hell which describes the carefully organized tours of the post-First World War battlefields. What horrified Kraus in 1921 was the effortless persistence of the discourses of tourism and advertising in the aftermath of catastrophe. He sarcastically wrote: "You understand that the destination has made the promotional trip worthwhile, and that the promotional trip was worth the world war" (Kraus, 1976: 92).
} 
fears and desires". There is something rather perverse in the aesthetic pleasure ${ }^{5}$ we clearly take in the plight of this city where the past is so achingly present as its citizens interact with the remnants of yesterday. But then again, to be fascinated by ruins has been a human tendency throughout the ages as Macaulay (1953) suggested in her magisterial Pleasure of Ruins in which she traces the development of its expression in literature and art from antiquity to her present day. Whilst we perhaps have always lived in a time of ruination, the $21^{\text {st }}$ century certainly appears to have thrown up its fair share of images of catastrophe and decay. We seem to live in a world populated by newly charred landscapes and the production of ruins where popular culture, as Zadie Smith $(2013$, p.2) pointed out, is characterised by a "post-apocalyptic scenario" which is "one of the most thoroughly imagined fictions of the age".

It should therefore not surprise us that 'ruin' is a concept of rising concern within the wider academy (Huyssen, 2010). Hell and Schőnle (2010, p.6) suggest that this "uniquely ill-defined" concept of ruin has been a source of fascination and inspiration for a wide range of academics, provoking many questions and often complex and contradictory responses. "The ruin is a ruin precisely because it seems to have lost its function or meaning in the present", they argue, and they go on to note that the ruin has "blurred edges" which provokes a whole series of allied questions:

"Is a well-preserved but empty building already a ruin because it has lost its practical and social function? And, at the other end of the spectrum, does rubble still qualify as ruin? More broadly, is a ruin an object or a process? Does it signal the loss or the endurance of the past?... Does the aestheticization of the ruin belittle the human suffering that it connotes, pushing us into morally dubious territory? Indeed, does the mass reproduction of ruins in various media numb our senses and trivialize horror? Or does it jolt us awake"?

\footnotetext{
${ }^{5}$ This takes the form of documentary film clips (e.g. https://www.youtube.com/watch?v=qTEIGtHXOT4), news paper commentary (e.g. http://www.nytimes.com/2012/01/19/opinion/dismantling-detroit.html), photo reportages, and even recent major motion films such as Jim Jarmusch's Only Lovers Left Alive and Ryan Gosling's Lost River where a post-decline Detroit provides an atmospheric background.
} 
Ruin then offers us no unified aesthetic and no easily applicable concepts, frameworks or ideas but rather, as Boym (2008) suggested, a meditation on ambivalence. We believe this is uniquely valuable at a time where there are increasing calls for organization studies to become a disciplined discipline (De Cock \& O'Doherty, forthcoming 2016). But this is not yet the place to spell out the relevance of ruin for organization studies in detail. First we must drift through the time and space of ruination, allowing ourselves and the reader to assemble insights along the way.

\section{A brief history of 'ruin lust'}

"The spectre of the city in ruins still haunts the contemporary imagination ... The ruination is real, and perhaps even permanent, but the images that are made of it are surely also the result of a specific, largely unconscious, desire; a fantasy according to which... the city [has] become once more, as the ruins of Palmyra were for Volney, a terrible warning about human ambition and hubris". (Dillon, 2014, p.30-31 - emphasis added)

The quote above is derived from the catalogue accompanying the eclectic Ruin Lust exhibition curated at Tate Britain during spring 2014. It speaks very much of the dual aspect of the ruin as both image and reality which offers a strange fusion of the abstract and the specific. This unusual combination of the imaginary and the real seems somehow to evoke the vastness of time itself (Smithson, 1996). Images of ruins denote raw reality, yet the way we see them is never 'raw' but always-already framed by long tradition of ruin gazing (Hell \& Schőnle, 2010). Indeed, there is a historic distinctiveness to the 'ruin gaze' that can be understood as the particular optic that frames our relationship to ruins (Boym, 2008). And the lesson is as simple as it is melancholic: "all cities, nations and authorities must, like men, meet their doom", as Scipio proclaimed on watching Carthage burn in 146BC (Hell, 2010, p.170). Imperial 
Rome itself constitutes of course one of the most enduring topoi in the vast ruin archive. If Rome can crumble, the ruin gazing tradition invites us to think, why not London or New York, or indeed modern Athens? The historical ruin gaze is thus allied to a sense of melancholia which sees ruins as emblematic of the transience of all earthly things and the certainty of obsolescence ${ }^{6}$.

A key work in the history of ruin gazing referred to above by Dillon is Comte de Volney's The Ruins, or Meditation on the Revolutions of Empires and the Law of Nature from 1791. Rising out of the Syrian Desert about 150 miles northeast of Damascus, Palmyra contains the monumental ruins of a once great city. Volnay's traditional soliloquy on the cruelty of time, the rise and fall of empires, and the inevitability of ruin is silenced by a genie that appears from the ruins and commands an end to such sentimental clichés. Ruin is not an inevitable cycle in nature, the genie proclaims, but rather the consequence of human pride, greed and stupidity. It was man, and man alone, who laid waste to Palmyra $^{7}$ (Hell, 2010; Woodward, 2002). We can thus see Volnay's work as introducing a politicized reading of ruin and ruination, something we shall return to shortly in our extended theoretical segue into the work of Walter Benjamin ${ }^{8}$. Inspired by Volnay, Hubert Robert was the first artist to paint an

\footnotetext{
${ }^{6}$ This particular ruin gaze persists into the $21^{\text {st }}$ century. Dickey (2015), for example, describes a trip to Pyramiden, a Russian mining town located in the Svalbard archipelago that was abandoned in 1998. He reflects on how thoroughly the place was reclaimed by nature and "what the world will look like without us, a world in which humans may exist and persevere, but in which human activity is no longer differentiated from nature, where human history has once again joined the deep geologic time of the earth itself... (p.11)"

${ }^{7}$ As we were rewriting this essay in summer 2015, Palmyra suddenly made it into the world news as the self-styled Islamic State (IS) were reported to have destroyed a number of the 2,000-year-old ruins after seizing the historic site. The BBC reported that the ruins of the temples of Bel and Baalshamin had both been 'reduced to rubble' (http://www.bbc.com/news/science-environment-34090536). On September $4^{\text {th }}$ the BBC posted a further report detailing the demolition of several funerary towers including the Tower of Elahbel dating from AD103 (http://www.bbc.com/news/world-middle-east-34150905). The status of Palmyra's ruins is now in some crisis as they are made to bear the imprint of another layer of destruction, but what readings future archaeologists might make of this brutal intervention will have to be inscribed in an as-yet to be defined set of political conditions of possibility.

${ }^{8}$ Without doubt the world-wide condemnation of the IS destruction of some of Palmyra's iconic ruins confirms what we might call the 'affective charge' invested in ruins. Whether Volnay's genie would be able to retain the critique of sentimentality in the light of the IS bombings remains moot, but we suspect this military or terrorist
} 
existing building, the Grand Galerie of the Louvre, as it might appear after a future catastrophe in $1796^{9}$. This brought to the fore another dimension of classical ruin gazing: as a way of thinking about and fearing for the future.

In the 1930s the ideas of 'ruin lust' and anticipated ruins took a sinister turn when Hitler introduced as official policy the 'Theorie vom Ruinenwert' (Theory of Ruin Value) where the ruin became a desired end goal of construction. Albert Speer thus started to execute vast building projects such as the Zeppelin Field in Nuremberg and the Reich Chancellery in Berlin which were modeled on a Rome-inspired imperial past, figured as glorious but built with an eye to their own potential as a future ruin which would enthrall the future Aryan ruin gazer (Woodward, 2002). Yet, as Hell (2010) drolly remarked, Hitler and Speer did not anticipate the ruin gazers to be the victorious subjects of the Allied Powers. In a much darker, but also redemptive reading, Sebald (2001, p.19) refers to the emotions evoked by such huge constructions born of arrogance and ambition, "a kind of wonder which in itself is a form of dawning horror, for somehow we know by instinct that outsize buildings cast the shadow of their own destruction before them, and are designed from the first with an eye to their later existence as ruins". This reading finds its visual echo in Anselm Kiefer's impressive painting Ashflower ${ }^{10}$, which reappropriates and reorganizes Nazi imagery and symbolism into something otherworldly as Speer's

targeting of ruins opens up another form of making-ruins-speak. Grappling with the ruin of our own language and thought in trying to make sense of these actions suggests it must remain a subject upon which it is premature to speculate.

${ }^{9}$ Another famous example is Joseph Gandy's 1830 painting of the recently built Bank of England (commissioned by John Soane, the architect who built it) as a fantastic labyrinth of broken columns, imagining how it might look hundreds of years in the future: http://www.soane.org/collections/soanes london/bankofengland/8

${ }^{10}$ http://www.theguardian.com/artanddesign/2014/sep/28/anselm-kiefer-royal-academy-review-rembembranceamid-the-ruins\#img-1. The painting was one of the centre pieces of the Kiefer retrospective which ran at the Royal Academy in London from 27 September until 14 December 2014. The idea of ruin is central to Kiefer's work as the title of his inaugural lecture at the Collège de France indicates: 'Art will survive its ruins' (Kiefer, 2011). 
ruined Reich Chancellery advances on the viewer like a ghost ship through fog, projecting its affective charge.

\section{The social organization of destruction}

"Just as there are plants that are said to confer the power to see in the future, so there are places that possess such virtue. For the most part they are deserted places [in which] it seems as if all that lies in store for us has become the past." (Benjamin, 2006, p.79)

Now our text has drifted into the territory of mad Nazi theories and the Second World War, we cannot but stop briefly to consider Walter Benjamin whose presence truly haunts modern writing on ruins (e.g. Hell \& Schőnle 2010, Roth, 1997; Sebald, 2004; Stoler, 2013). In the Origin of German Tragic Drama Benjamin (1926/2009, p.178) already wrote about how history actually becomes present in reality in the form of the ruin, and "in this guise history does not assume the form of the process of an eternal life so much as that of irresistible decay". For Benjamin it was the exposure to ruin that could help animate dormant energies, precipitating the awakening of a revolutionary consciousness. In this vein he attempted to seize the processes of ruination that inhabit the anonymous and timeless little squares that periodically appear while wandering through the streets of Paris. He did this by the deployment of a language that captures the complex play of space and time, of nature and culture, noting in an exemplary piece of writing that houses appear to "have slowly, sleepily, belatedly assembled in response to the summons of the century" (Benjamin, 2002, P1, 2). Such a Benjaminian ruin optic opens up "a prospect onto history from which the false glimmer of categories such as totality, coherence and progress has been stripped away" (Eiland and Jennings, 2014, p.229). For Benjamin the knowledge of ruin interrupted dominant modes of temporality in which we assume we look forward into the future. Thinking with and inhabiting the ruin, Benjamin could only see future events in those instances where 
they had already moved into the past. In Berlin Childhood around 1900 (Benjamin, 2006) he somehow tried to find a way backwards into a future, which, although it had been abandoned by then and its idea had been perverted, still held more promise than the images of the future his present had to offer. Writing in the 1930s, Benjamin was painfully aware of the coming catastrophe and of what precisely had been lost already, both personally and collectively. He therefore wanted to present history in such a way that it continuously engaged "a constellation of dangers" (Benjamin, 2002, N10a, 2) and led the past to "bring the present into a critical state" (N7a, 5) so as to allow the promise of a different kind of future. The moment of awakening from the horrors of history begins when "we begin to recognize the monuments of the bourgeoisie as ruins even before they have crumbled" (Benjamin, 2002, p.13; emphasis added). Benjamin thus brought to the fore a politicized reading of ruins, treating them as both symptom and substance of (human) history's destructive force (Stoler, 2013). This is a notion of ruin not as the romantic vestige of the corrosive effects of time, but as both remainder and reminder of humanmade disaster.

In his famous Zurich lectures on the bombing of the German cities during the Second World War, which end with an extensive quote from Benjamin's Theses on the Philosophy of History and specifically his Angel of History (Benjamin, 1999; De Cock et al., 2013), Sebald (2004) described in some detail what he calls 'the social organization of disaster' which seems to underpin the ever-recurrent and everintensifying horrors of history.

"A million tons of bombs... 131 towns and cities mostly flattened; 600,000 German civilians fell victim to the air raids; three and half million homes destroyed... Seven and a half million people left homeless... 42.8 cubic metres of rubble for every inhabitant of Dresden". (p. 3-4)

The strategic aim of the bombing offensive, bringing the end of the war closer, remained unfulfilled as the morale of the German population remained unbroken and German industrial production was only 
impaired marginally. And yet, for organizational reasons, the aims of the air offensive were not modified, a fact that for Sebald has been largely ignored in the official histories. Sebald very much sees this systematic destruction arising from the development of the means and modes of industrial production:

"[T]he organizational dimension of the bombing offensive... had such a momentum of its own that short-term corrections in course and restrictions were more or less ruled out, especially when, after three years of the intensive expansion of factories and production plants, that enterprise had reached... its maximum destructive capacity. Once the materiel was manufactured, simply letting the aircraft and their valuable freight stand idle on the airfields of eastern England ran counter to any healthy economic instinct". (p.18)

In a 1952 interview Brigadier Frederick L. Anderson of the U.S. Eighth Army Air Force expounded that the bombs they had brought were, after all, "expensive items." "In practice, they couldn't have been dropped over mountains or open country after so much labor had gone into making them at home (p.66)." Sebald then goes on to spell out precisely the link between organization and ruination:

“From the organizers' viewpoint... so much intelligence, capital, and labor went into the planning of destruction that, under the pressure of all the accumulated potential, it had to happen in the end... The result of the prior claims of productivity, from which with the best will in the world neither responsible individuals nor groups could dissociate themselves, was the ruined city laid out before us" (p.66 - emphasis added).

Sebald's idea is that a proper understanding of the catastrophes we are always setting off - an understanding that involves the organization of materials, people, and institutions - is the prerequisite of organizing for something different. It is therefore paramount to salvage the knowledge of destruction 
before the onset of oblivion ${ }^{11}$. Sebald's body of work invites us to share the experience of hubris and his writings and practices can function as a practical guide to dwelling in our modern ruins. Indeed, one need not look at such an extreme case as the Second World War to become sensitive to the social organization of destruction and our implication in it. Although largely overlooked when compared to the research and social significance devoted to consumption and production, processes of destruction are all around us and are intensifying (González-Ruibal, 2008). The most obvious and visible artifacts in this overlooked ghostly world of decaying modern debris are the derelict factories and office buildings, the closed shopping malls, the redundant and abandoned towns and islands (Decker, 2013; Edensor, 2005; Lavery et al., 2014).

\section{Exploring modern ruins}

"Whatever future used to burn in our memories, the past was a continent that someday will be discovered". (Gelman, 1997, p.77)

The first interest in 'modern ruins' can be pinpointed to October 1967, with Robert Smithson's essay on 'The Monuments of Passaic' in Artforum. Smithson took a bus from the Port Authority terminal in Manhattan to the outskirts of the city of Passaic and wrote about the expedition in a kind of ironic travelogue which blends texts and photographs. He would later describe Passaic as "a kind of rotting industrial town... somewhat devastated... [with] an ambience where everything is chewed up" (Smithson, 1996, p.298). Passaic as seen through Smithson's eyes is some kind of half-imaginary place stranded between utopia and catastrophe. He documents an industrial wasteland full of factory relics that represents a contemporary eternal city, containing monuments to rival the architectural treasures

\footnotetext{
${ }^{11}$ This was very much one of the aims of another recent major cultural event where ruins played a central role: the Conflict • Time • Photography exhibition curated at the Tate Modern, 26 November 2014-15 March 2015. The front cover of the exhibition catalogue features Richard Peter's iconic photograph, Blick vom Rathausturm (View from City Hall), of Dresden in ruins after the Allied bombing raids.
} 
of ancient Rome. These desolate, forlorn 'monuments', including a pumping derrick, drainage pipes, a parking lot, and a bridge he names 'Monument of Dislocated Directions', become transfigured into aesthetic reveries in his essay (Merewether, 1997). The monuments Smithson photographs and describes seem somehow caught in a dialectical state between being built and falling into disuse and decay, and in representing them thus he makes, "the future look old-fashioned and the past seem as if it has arrived from some unknowable time to come" (Dillon, 2011, p.14). It is in particular the notion of 'ruins in reverse', in which construction and dissolution cannot be told apart, that would inspire artists and writers over the next few decades (Dillon, 2014). It is worth quoting Smithson (1967) at some length in order to let this notion of 'ruins in reverse' breathe a little:

That zero panorama seemed to contain ruins in reverse, that is all the new construction that would eventually be built. This is the opposite of the 'romantic ruin' because the buildings don't fall into ruin after they are built but rather rise into ruin before they are built. This anti-romantic mise-en-scène suggests the discredited idea of time and many other 'out of date' things... Passaic seems full of 'holes' compared to New York City, which seems tightly packed and solid, and those holes in a sense are the monumental vacancies that define, without trying, the memory-traces of an abandoned set of futures. Such futures are found in grade B Utopian films, and then imitated by the suburbanite... I am convinced that the future is lost somewhere in the dumps of the non-historical past; it is in yesterday's newspapers, in the jejune advertisements of science fiction movies, in the false mirror of our rejected dreams. (p.49-51)

Smithson introduces here a sense of hovering between a recent past and a future that has not come to pass, thus making us aware of the vagaries of progressive vision. Like Walter Benjamin he seeks the future in the past, in the memory-traces of what was to come. The future was yesterday and we barely seem to have noticed Smithson suggests. In confronting us with the foreclosed futures of a different era, 
Smithson emphasizes the power of contingency in history. Every particular present, he reminds us, always has its own particular dimension of futurity, of fears and expectations, which (realized or not) inevitably accompany that present into the past (Jameson, 2013). And it is precisely this sense of having survived the collapse of past dreams of the future and the nostalgia for a redeemable pastness that is key to the ruin optic that still animates many artists today (Dillon, 2011). At their most powerful ruins make us think of the past that could have been and the future that never took place.

This strange aspect of ruins to evoke multiple temporalities was very prominent in an exhibition held at Finsbury Park London during the summer of 2014 by Mexican artists Ivan Puig and Andres Padilla Domene. They built their own 'Abandoned Railways Exploration Probe', a car converted for rail travel which seemed to have come straight out of a 1960s science-fiction movie, to travel Mexico's abandoned railways. During their travels they documented how thousands of kilometers of track have fallen into disuse and are going to waste since privatization of the national railway system in the 1990s. One photograph features their 'car' in a salt mine at night and the intended futuristic effect is quite stunning: it seems as if they have just arrived in a lunar landscape. Puig and Domene's film and pictures document a melancholic journey into the past with desolate stretches of track decaying into the landscape; but they also connect to a dystopian future, as the artists conjure up overlooked people, places and processes in world that is slowly reverting to jungle ${ }^{12}$. They thus explore how the ideology of progress is imprinted onto the landscape and make us aware of the complex relationship between human, historical and natural temporalities. Theirs is a journey into what they explicitly refer to as 'modern ruins': places and systems left behind quite recently, not because they were not functioning, but for a range of political and economic reasons. Look closely and you will notice we already dwell in the ruins of modernity they tell us. And they achieve this effect by configuring a relationship between past, present

\footnotetext{
${ }^{12}$ An excellent short video of their journey can be found at http://www.youtube.com/watch?v=ToutMFKsv44
} 
and a (possible) future that moves between the fantastic, the affective and the dystopian, all the while pointing out the stupendous waste and wreckage created in our modern day economies.

\section{Insert figure 2 about here: Abandoned railways exploration probe - multiple temporalities}

\section{Ruin and Organization Studies}

"This transformation of material content into truth content makes the decrease in effect, whereby the attraction of earlier charms diminishes decade by decade, into the basis of a rebirth, in which all ephemeral beauty is stripped off, and the work stands as a ruin... such ruins have always stood out clearly as formal elements of the preserved work..." (Benjamin, 2009, p.182).

At this point we intend to bring to the fore the ruin's visual poignancy through reflections on our own field work. Our first excursion follows very much in Sebald's footsteps (2002) as we visited the modern ruins of Orford Ness on the Suffolk coast. Sebald's original journey, as he wandered among the ruins at the edge of the sea trying to connect them, in a most unsystematic way, to the violence of our recent history, has been described as "a meditation on the physical, conceptual, and narrative ruins of modernity" (Presner, 2010, p.209). Orford Ness was requisitioned by the War Department in 1913 and until the late 1970s remained a secret weapons testing centre of the UK Ministry of Defence. It was the site of experiments in radar, defence systems, bombs, and atomic weapons. Much of the experimental work related to aerial warfare and the bombs dropped on the German cities are very likely to have been first tested here. But it is the legacy of Orford Ness' involvement with the research and development of the British atomic bomb, much of which remains classified information, which gives the place a certain 
mystique. It was acquired by National Trust in 1993 and later opened to the public. The site is based on a ness, the head of a long neck of shingle which for 16 kilometres runs parallel to the coast south of the town of Aldeburgh, and faces the village of Orford from where one can cross the river in a small National Trust boat once an hour. This provides a natural way of managing the access and thus protecting the remoteness and aura of the site. The Trust took the decision to preserve the site in its decay; to retain evidence of past use but at the same time to allow natural processes to run their course ${ }^{13}$. They thus acknowledged that whilst the objects and sites we frame as 'ruin' are vulnerable to the threat of decay, if we care too much for them their very status as ruin becomes threatened. Or as Roth $(1997$, p.2) put it, "Ruins resist their own decay because they persist, but not too well".

\section{Insert figure 3 about here: In Sebald's footsteps - a visit to Orford Ness}

The first impressions one collects as one walks from the landing site to the central cluster of decaying military installations are of the famous 'pagodas' which were built to carry out tests on the components of atomic weapons, and designed to absorb and dissipate an explosion in the event of an accident. Our photograph of these huge labs with sheep lazily grazing in the foreground is eerily reminiscent of Sebald's (2002) picture of the pagodas which was reproduced in his Rings of Saturn. He wrote:

"My sense of being on ground intended for purposes transcending the profane was heightened by a number of buildings that resembled temples or pagodas, which seemed quite out of place in these military installations. But the closer I came to these ruins, the more any notion of a

\footnotetext{
${ }^{13}$ For example, the slab of concrete on which one of the authors is sitting on in the photograph was part of a watch tower that was washed away in a big winter storm the previous year, thus illustrating Boym's (2008) point that ruins give us a shock of vanishing materiality.
} 
mysterious isle of the dead receded, and the more I imagined myself amidst the remains of our own civilization after its extinction in some future catastrophe" (p.236).

As one approaches the centre of the site one walks past vast shingle expanses, some of which must surely be one of the most bombed pieces of land on the planet. Strewn amongst the shingle are pieces of scrap metal and concrete, and both old and new 'Danger - No Access' signs can be found everywhere. As we learn about the story of these strange modern ruins from story boards placed in some of the better preserved buildings, we can imagine the hive of activity Orford Ness once must have been with thousands of people working there. The material ruins we encounter there now function as a synechdoche for those people as their absence manifests itself as a presence through the traces we encounter of their past activity and the strange objects we only half recognize. The fact that life with its wealth and its changes once dwelled here constitutes an immediately perceived presence (Simmel, 1958). These ruins speak of the past, of how something is framed as a trace of a world to which we no longer have access, except in those rare moments "when a constellation of contingencies creates a kind of equipoise, when for some reason (who knows why?) we are given access to - we are overcome with a time that is not our own" (Roth, 1997, p.18). As Sebald (2002) put it poetically,

"To me too, as for some latter-day stranger ignorant of the nature of our society wandering about among heaps of scrap metal and defunct machinery, the beings who had once lived and worked here were an enigma, as was the purpose of the primitive contraptions and fittings inside the bunkers, the iron rails under the ceilings, the hooks on the still partially tiled walls, the showerheads the size of plates, the ramps and the soakaways. Where and in what time I truly was that day at Orfordness I cannot say, even now as I write these words" (p.236-237). 


\section{Insert figure 4 about here: Haunted by absent presences}

Wandering around Orford Ness, one certainly becomes sensitized to the potential of ruins as "routes out of our own moment - portals into past, present and future" (Dillon, 2014, p.53). They have the capacity to spill out of the present into our sense of the past and our expectations of the future. Our ruin gazing or ruin wandering is a way then of setting ourselves adrift in time somehow, providing an antidote to our strandedness in the now that leads to an obliviousness of human historicity and radically reduces our imagination to the realm of the present (Eshel, 2010). Jameson $(2015$, p.120) talks in this respect about "the historically strange and unique phenomenon of a volatilization of temporality, a dissolution of past and future alike, a kind of contemporary imprisonment in the present... an existential but also collective loss of historicity in such a way that the future fades away as unthinkable or unimaginable, while the past itself turns into dusty images and Hollywood-type pictures". It is precisely a heightened sensitivity to ruin and ruination that offers the possibility to break through our current paralysis and make "present, past and future once again open up in the full transparency of their distances (Jameson, 2009, p.598).

The future as yesterday is also readily available in the contemporary ruins of the high street in UK towns and cities. This has become a matter of some public controversy as new online digital media and the proliferation of out-of-town shopping centres reconfigure the site of consumption. As many have noted, city centres are now increasingly marked by row after row of boarded-up shops and abandoned buildings, of razed plots of land taken over by Himalayan balsam and Japanese knotweed, transient fastfood and pizza take-away parlours opening and closing to the rhythm of the university calendar, bargain basement charity shops, and a 'night-time economy' built on drinking warehouses, violence and excess. 
Indeed, the typical city-centre is becoming a space that resembles Smithson's Passaic (Roberts, 2006). These future ruins were always present, but back in 1993 when one of us was embarking on a pilot research project launched to scope out the parameters for an empirical project in the banking and financial services industry, there was optimism in the air: banks were expanding and commercialising their products and services, whilst the promotion of consumption as a form of leisure and recreation was helping to revitalise city centres.

The research was designed to explore the organizational consequences attendant upon the use of new technology and the changing patterns of employment this encouraged. Carefully constructed semistructured interview questionnaires were prepared so that the research could gather data that might offer insights into the changing role of the middle manager and the possible de-skilling of the traditional branch manager as new forms of expertise and occupational specialisms 'took over' the high street bank (see also Knights and Willmott, 1992; Knights and Morgan, 1995). Determined to gather valid data that were reproducible and generalizable, the researcher made stringent efforts to stick to the interview script. However, during one interview with a branch manager in King's Heath high street in Birmingham, the researcher began to notice the strange hieroglyphics and looping patterns, scribbles and asides that were proliferating absentmindedly as notes and jottings made in the margins of the questionnaires. Like the "acanthus leave one used to copy in school... or the curved wrought iron, 'modern' style of the [Paris] Metro entries" (Leiris, in Derrida, 1982, p.xi), and which might have attracted the gaze of Benjamin on the Paris subway, these "wreathed, coiled, flowered, garlanded, twisted, arabesque" jottings intruded onto the carefully bounded space reserved for the linear writing of interview notes. Looking back over these notes compiled during six months of interviewing, the researcher was shocked to discover that page upon page was similarly marked, almost ruined one might say. 
What was carried both in the content and the form of this ruinous writing was anathema to the kind of empirical data usually considered legitimate in organizations studies. It took a tremendous effort to retain the kind of vigilance required to police the borders of the interview and record only that which was 'officially' on the record and that would provide data to help advance tried and tested organizational theory. As in Collinson's (1992) work, the manager being interviewed was earmarked for the role of 'critical narcissist': evidence was there to indicate that fragile masculine egos were being shored up by projections of inadequacy onto others in the bank, a response to the experience of insecurity that was beginning to be felt as administrative centralisation and new technologies were breaking up the integration of the traditional branch and the wider occupational bank structure, creating narrow specialist 'silos' into which those trained as 'all-rounders' could see little progression or role for themselves. It was even possible that this data could be used to extract the 'paradox of identity' (Knights and Willmott, 1999), or the vicious circle of control and resistance, in which preoccupations with identity preclude an exploration of the wider shared and social conditions of power and inequality that produced the insecurity in the first place. The project was reaching a moment of possible triumph, but then ruin...

Suddenly, with the manager still droning on in the background, I became aware of the noise of the traffic as it rumbled outside, the branch shaking, small dust motes were falling like leaves or a projection of visual hallucination commonly referred to as 'seeing stars' and technically known as 'phosphene'. A constant hum and vibration: ambient and omniscient, it is under my feet, in the walls, a persistent tic-tic of a faded Constable picture (The Hay Wain) on the long partitioned wall; even my writing is being inflected, slightly, by the trembling. The quality of the light is poor, sepulchral. The walls are not so thick or impressive, in fact they are partitioned walls that have been hastily assembled, joined together with long vertical strips of brown plastic trim. I write in the margins of my notes: David must be ... what? 55 
years of age? Corpulent and fleshy, he seems to slump now. Can you see the lines and the weariness under his eyes? I suppose he could be my father. A family tree, somewhere here within this branch. My thoughts perhaps triggered by his silver framed photographs standing up on the desk between us. Two late-teenage boys, and a mother, all of them smiling, her hand gently placed on the shoulder of the tallest of the two boys. Another photograph shows one of his sons in a graduation gown, his degree certificate rolled up as is the custom, held in his right hand, pointing upwards towards his father's desktop computer screen. How can I talk to David about this? And then again, I am struck by a remarkable vision. David is now redundant; this branch is closing down, held up by scaffolding and RSJ beams and braces, the windows all smashed, the walls mildewed, abandoned steel grey filing cabinets, and paper fluttering across the floor...

Notes from Researcher's Diary, November $12^{\text {th }} 1992$

This sudden intrusion of "intertwined time" and its accompanying "heightened graphicness" (Eiland and Jennings, 2014, p.291) introduces ambiguity and the possibility of an alternative reality that appears superimposed upon the previously established dominant reality which was formed by academic concepts, theoretical structure, formal interview protocols, organograms, official titles and organizational roles (e.g. interviewer/interviewee, branch manager). Two different forms of sensemaking appear here. The first is more cognitive in nature and more orthodox, discursively more technical or quasi-scientific, respecting the customary boundaries of social science and interview based research - it a is familiar world even though the concept of 'critical narcissist' might not enjoy wide currency. The second seems to lose these structures as it opens out into an extended meditation on organization triggered by a breach in the division between researcher and researched. The interviewee is no longer a 'manager', and no longer a representative of abstract academic theory in which he might be cast as an 'agent of capital' or a 'subjectivity', or - in more recent typologising - a 'mentor', 
'expressive manager', 'sergeant', 'micromanager' or an 'amateur manager' (Martin, 2013). Instead, the two realities flicker, akin to the old woman/young woman optical play common to introductory organizational behaviour texts but first sketched by British cartoonist W.E. Hill (1915). Like Sebald's experiences on Orford Ness, these two realities are brought together in a temporal breaching of sequence and linear ordering. Yet, these two realities are never fully-formed or complete. Instead, one acquires a sense that they are possibilities or patterns that await gestalt, both remaining dependent in part on the disposition of the researcher; they are in other words transient and reflexively maintained through the participation of the researcher and the researcher/researched relation. The affective tenor that attends this breaching experience might be experienced in quite disconcerting ways, but in opening to the full range of materials and qualities which are so easily displaced in organization-studies-as-usual, there emerges the possibility of a more prosperous and variegated set of relations from which organization might be assembled.

Crucial to this opening was the collection of marginalia in the interview notes, seemingly collected on the basis of random and at first glance trivial associations, asides and aide memoires, and forming what we might call after the well-cited phrase of Mary Douglas (1966) 'matter out of place'. On closer inspection this actually provided an alternative range of material that encouraged us to see patterns of organization that extended beyond and outside the confines of the bank or this particular branch of the bank - both of which operate at different scales but are typically thought of as discrete units of organization. We sacrifice a certain amount of precision (itself an artefact of more positivist methods of study) in this move; but pursued with its own rigour it can lead to something approaching the 'revelatory' or 'truth content' that we have been citing from Benjamin, for whom certain meanings were only possible to grasp when they became withdrawn from 'useful' reality through a process of ruination. Relaxing the relational defences afforded by academic and conceptual vocabulary, the researcher finds 
resources for empathy and communication, triggering something equivalent to that form of 'care' associated with an existential literature. Most telling is that the ethnographic notes here reveal the productive destabilisation of 'matter and memory' (see Bergson, 1896/1988), as personal memories intrude to provoke associations that take us into 'intertwined' time, in a sense, finding a spatiotemporal conception where the public and private, memory and history, meet and dissolve their boundaries. The anthropologist Yael Navaro-Yashin (2009) calls this the 'space of ruination', but there are few traditions or resources within organization studies that might help us develop this form of ethnographic research.

Ruination here is not idle metaphor but takes place between the subject and object, or between the habitual dualisms we typically identify as the 'interiority' of the psyche, for example, and the 'exteriority' of matter in the environment: neither is it in itself responsible for the affective experiences that transpire. Rather, it is the relational qualities that are stimulated and drawn out by the transgression of this artificial dualism subject/object or inside/outside. In other words, there are distinctive qualities that emerge into consciousness when the boundaries of the (humanist) self are breached and we begin to admit a fuller range of material and affective forces into our consideration of organization. In many ways this opens researchers to the possibility of experiencing the ruin in a palpable and materialist way. The ruin lies like a hidden blueprint behind the ostensible reality of buildings and walls, offices, furniture, organizational charts, mission statements and all the other accoutrements of rational organization, but fragments of this becoming-ruin are evident if one can learn to look out of the corner of one's eye. The flecks of paint peeling from the walls, the carpet worn under the pressure of human traffic, the fading photographs on the wall, are all imprints of a time in organization that anticipates ruin writ large.

At the same time, during this breach it becomes unclear who or what is responsible for experience, and as this experience draws us out of ourselves we enter a wider set of relations within which we can begin 
to understand organization. Entering the space of ruination marks the difference between 'affect' and 'emotion' (Flatley, 2008; Jameson, 2015), and drawing on elements of the work of Spinoza, NavaroYashin shows how groups and communities can become mobilised by affect in ways that render organization contingent and always riven by lines of tension and trigger-points that remain volatile and largely unpredictable. Her specific interest lies with a community of Turkish-Cypriots who are living in buildings and spaces that were inhabited by Greek Cypriots prior to the 1974 war that led to their expatriation and the construction of a border and UN buffer zone dividing the island of Cyprus. She tracks the effects of melancholy as expressed by Cypriots in their vernacular 'maraz' which she begins to understand as a "mark of the energy discharged upon them by the dwellings and environments" they have lived in for decades (Navaro-Yashin, 2009, p.4). People talked of finding rotten food on the tables of the abandoned Greek buildings that were taken or allocated for them to live in. Everyday objects of domesticity - furniture, clothes and cooking utensils - thus trigger a 'world of imagination' in which inhabitants are also reminded of the memory of a lost sociality.

There is an 'othering' that takes place here, one that 'extends' subjects in space and time and which renders them receptive to experiences that are both pre-individual (shared and collective) and 'constitutive' - in other words, the experience folds back to inflect the tenor and manner of that which is presumed to be an organizational present. The experience of ruination opens up a multiplicity in Deleuzian terms (e.g. Deleuze, 1994, p.182), it acts on both subject and object, displacing the fixity of its relation that is held in place by a complex interplay of the comportment that derives from unstated understandings of how things work in the world - habits of heart and mind - and what we might call pre-conscious existential identity (Stoler, 2010). But this doubling is one that is shared between researcher and researched; indeed the opposition researcher/researched begins to lack rigour and legitimacy. Hence, it takes a great deal of sensitivity and skill to enter these worlds and it requires 
preparedness for participation and transformation - a classic motif, if not the sine qua non, of ethnographic research. There is an experimental quality to this participation, a risk with a set of unknown and somewhat uncontrollable outcomes. Navaro-Yashin does not elaborate on the conditions of possibility that might explain the particular reactions to ruins and ruination she develops in her paper, but she does follow a fairly orthodox reading - namely that ruins are the trigger for experiences of loss, melancholy, memory and mourning, temporal disjunctures, transience, futility, etc. (Dillon, 2011; Stoler, 2013). There is also a redemptive quality to her ethnography: a quest to find ways of healing, of synthesis and recovery, making that which is lost whole again. In this way, her writing retains strong affinities with Benjamin's (1999) Angel of History.

The study of 'affect' and the agential properties of 'non-human' objects and relations has attracted considerable interest across the social sciences (Bennett, 2010; Coole and Frost, 2010; Gregg and Seigworth, 2010), and some of the most fruitful applications are to be found in the innovations this has inspired in ethnographic study (Kohn, 2013; Reeves, 2014; Stewart, 1996, 2007). There are other possibilities and other resources that might be found through ruination, and this is what Walter Benjamin was interested in: the stimulus to politicisation and re-politicisation, the discovery of new capacities, new modes of relating, and the recovery of forgotten ways of organizing - the by-waters and backwaters of organizational history that tend to get occluded in the forward march of homogenisation and linearity (cf. De Cock et al., 2013; Eiland and Jennings, 2014). There are implications here not only for the way we might conduct empirical research, but also how that research might be written. We have explored the way Sebald seeks to conjure an affect of ruin; his juxtapositions and digressions evoke in the reader an empathetic engagement, triggering memories and associations that for some might approach epiphany-like experiences. They also signal a reserve when it comes to completeness; a restraint from filling the entire meaningful space. We have followed Sebald, albeit tentatively, in his use 
of photographs and vivid description of memories (see our text box above) as a possible means of mediating or re-actualizing material 'presence effects' (Gumbrecht 2004), thus teasing out ephemeral simultaneities between presence and meaning that characterize our material encounters.

All this is difficult to conceive as a possibility within the confines of a traditional academic journal article, but Taussig has found ways of experimenting with form (e.g. Taussig, 2012) in ways that might inspire similar efforts in organization studies. It is not as if the Academy of Management Review or Academy of Management Journal is not engaged in a politics of affective space. It is just that the affect here is possibly less foregrounded but it is nonetheless at work, perhaps most so in the form of a politics of pacification (De Cock and Jeanes, 2006) or anastheticisation (Dale and Burrell, 2003). The rationalcognitive form can be used in the pursuit of many different politics, of course, but for us organization studies in ruin demands a form consistent with a sense of urgency and crisis. Our current domestic political institutions and the form in which we understand and practice politics seem inadequate when one considers the scale of the contemporary economic and ecological challenge, a challenge that takes us beyond the terms of reference within which the 'nation state' and 'individual' can operate, and indeed outside of the relation between state and civil society, or the state and the individual, those two most modern of all social scientific concepts. At a time when organization theory has been described as a "living museum of the 1970s" (Davis, 2010, p.691), when organizational scholars are "questioning the capacity of organization theory to engage with the phenomena it purports to describe and explain" (Holt and den Hond, 2013, p.1589), and when concepts and meanings from other areas of intellectual inquiry always seem to be "neutered and sanitized during their translation in OMT [Organization and Management Theory], rather than radicalized and extended" (Suddaby et al., 2011, p.239), we hope to have shown how the ruin optic reveals new analytic spaces and associations - without lining them up too smoothly though. 


\section{Conclusion}

"The frightening problems are the ones that really need investigation". (Smithson, 1996, p. 231)

"It won't be our capacity for despair that does the race in; we are damned by how easily we shrug the darkness off". (Powers, 2011, p. 8)

Our essay has explored the ways in which a ruin optic retains plurality, ill-definedness and transgressive force and thereby resists easy incorporation and sanitization into a particular field. This is perhaps the main contribution we have to offer this series of essays that seek to advance the idea of ' $X$ and organization studies'. We have also shown that working with ruins cannot be divided into any simple epistemological and ontological division. Perhaps the fate of our paper is to be strangely 'out of time' in the main current of organizational theorising as it has so obviously sought to resist grafting its findings into any obvious continuity with past theorizing. Yet, this abandonment of the usual strategies of organizational discipline in which the authors claim a legacy and a future bequest is also perhaps its possible strength. The hubris of every form of futurism is that it must remain blind to its own built-in obsolescence; in other words every prospect of the future contains, embedded within it, the notion of a ruin (Smithson, 1996). And the same goes for theories: eventually any theory will turn against itself and will be refuted or simply disappear into oblivion. As such the ruin continuously interrogates our epistemic habits and formations.

If there is a 'lesson' to emerge from our cases it concerns the deep connection between time, memory and spatiality that has remained largely under-researched and under-conceptualized in organization studies (Decker, 2014). Ruins are spatial allegorical manifestations of the processes of remembering, of 
its impossibilities and multiplicities (Edensor, 2005). Through a reactivation of the memory of a circumstantial past the ruin optic can oppose the official chronicles of history and thus open up a space where new possibilities for the future can be imagined and where we can read our present condition other than simply the continuation of a preceding series; what history could have been, yet did not become. Whereas mainstream (business) history (viz. Rowlinson et al., 2014) seeks meaning and purpose in the process of history and tends to throw a backward-directed glance toward what has been, factum est, and has therefore already become necessary; the ruin makes us aware of the arbitrariness of human action, or what Kant (quoted in Arendt, 1978) referred to as the 'disconsolate haphazard' (trostloses Ungefähr - Waible and Herdina, 1997) of the particular. Traditional ways of thinking about history are a solution to this contingency by producing closure. The effect of this, as Arendt (1978, p.30) explains, is that "The impact of reality is overwhelming to the point where we are unable to 'think it away'... because it now turns out to be impossible for us to imagine a state of affairs in which it [the past] had not happened". Ruination, by contrast, confronts us head-on with the problem of the particular that can no longer be made meaningful in terms of its place in an overarching process called progress. It shows not just what has been but that 'it could have been otherwise'.

We have tried to show and enact in our ruinous writing that a ruin optic is always replete with interruptions, unintelligible signs and improvised stories and memories which emerge from the ruin and which talk back to other stories about the past, thus bringing back into consciousness the vague, disjointed stories of the forgotten and the neglected which haunt 'official' narrative fixings (Edensor, 2005). As Simmel $(1958$, p.358) put it in his classic essay on the ruin, "It is as though a segment of existence must collapse before it can become unresisting to all currents and powers coming from all 
corners of reality". The ruin optic we put forward here then aims to open up the "grey spaces' ${ }^{14}$, those "death zones of dystopian incursions" (p.96) and these "slag heaps of our collective existence" (p.63), Sebald (2004) writes about so eloquently. It tells us that we are, and always have been, dwelling in the ruins.

The reason for our general fascination with ruin and ruination, a fascination which goes far beyond what is merely negative, is the widening of our understanding of organization and the different forms of research practices that it enables. Captured as we are in the "aesthetic of the absolute present" (Jameson, 2013, p.300), we have elevated the skill of 'not looking', or more precisely 'looking and looking away at the same time' to an art form in organization studies, thus imposing an unseen and unacknowledged 'cordon sanitaire'. Burrell (1997), for example, noted the profound silence in organization studies regarding the organization of the holocaust and pointed more generally to the suppression of crucial dimensions of the human condition. We should never underestimate people's ability (and we include organizational scholars here of course) to forget what they do not want to know and to overlook what is there before their eyes. When Sebald $(2004$, p.10) talks about the horror "threatening to overwhelm any who really looked at the ruins around them" we wonder whether something similar is at work in our field where we simply carry on our scholarship as if nothing momentous is happening all around us.

This might explain our inability to adequately assess the danger of the ecological and economic/financial catastrophes insidiously creeping up on us as many of us still twitter on endlessly amongst ourselves about 'multiple institutional logics' or whatever is the current intellectual fashion. Stoler (2010, p.256)

\footnotetext{
${ }^{14}$ This is a riff on the recent 'White Spaces' (O'Doherty et al., 2013) and 'Dark Side' (Linstead et al., 2014) special issues that were published in this very journal.
} 
refers to "this ability to excuse oneself from wrought engagement, this refusal to witness..." and the "blinding near-sightedness of circumscribed community that sets out the proper limits of care and why it makes sense for a community not to concern itself more broadly...", as the "well-intended conditions of disregard". These conditions of disregard "are located in the implicit meanings people assign and reassign to their own acts and agency", and thus neutralize experiences beyond people's ability or willingness to comprehend. We believe a ruin optic can makes us more aware of the disjointed and neglected materialities and narratives buried beneath the surface of organization-studies-as-usual, whilst all the while pointing to the excessive presentness of disaster (Blanchot, 1995). Learning to embody and deploy such an optic then, has the potential to unsettle fundamental social imaginaries in the present which hold us all in thrall and may thus in a modest way help prevent man-made catastrophes from taking root in our cultural imaginary as natural disasters that absolve us of all agency and responsibility in the matter. 


\section{References}

Arendt, H. (1978). The Life of the Mind. New York: Harcourt Brace.

Benjamin, W. (1999). Illuminations (H. Zorn, Trans.). London: Pimlico.

Benjamin, W. (2002). The Arcades Project (H. Eiland \& K. McLaughlin, Trans.). Cambridge (MA): Harvard University Press.

Benjamin, W. (2006). Berlin Childhood around 1900 (H. Eiland, Trans.). Cambridge (MA): Belknap Press.

Benjamin, W. (2009). The Origin of German Tragic Drama. London: Verso.

Bennett, J. (2010). Vibrant Matter: A Political Ecology of Things. Durham: Duke University Press.

Bergson, H. (1988) Matter and Memory. Brooklyn, New York: Zone Books.

Blanchot, M. (1995). The Writing of the Disaster. Lincoln: University of Nebraska Press.

Boym, S. (2008). Architecture of the Off-Modern. New York: Architectural Press.

Burrell, G. (1997). Pandemonium: Towards a Retro-Organization Theory. London: Sage.

Collinson, D. L. (1992). Managing the shopfloor: Subjectivity, masculinity and workplace culture (Vol. 36). Berlin: Walter de Gruyter.

Coole, D., \& Frost, S. (2010) (eds.) New Materialism: Ontology, Agency, and Politics. Durham: Duke University Press.

Dale, K. \& Burrell, G. (2003). An-Aesthetics and Architecture. In A. Carr \& P. Hancock (eds.), Art and Aesthetics at Work: 155-73. Palgrave Macmillan.

Davis, Gerald F. (2010). Do theories of organizations progress? Organizational Research Methods, 13: 690-709.

Decker, S. (2014). Solid intentions: An archival ethnography of corporate architecture and organizational remembering. Organization, 21(4): 514-542.

De Cock, C. \& Jeanes, E. L. (2006). Questioning Consensus, Cultivating Conflict. Journal of Management Inquiry, 15(1): 18-30. 
De Cock, C., O'Doherty, D., \& Rehn, A. (2013). Spectres, Ruins and Chimeras: Management and Organizational History's Encounter with Benjamin. Management and Organizational History, 8(1): 1-9.

De Cock, C. \& O'Doherty, D. (2016). 'Management as an Academic Discipline' in A. Wilkinson, S. Armstrong and M. Lounsbury (eds.). The Oxford Handbook of Management. Oxford: Oxford University Press.

Deleuze, G. (1986). Cinema 1: The Movement Image (H. Tomlinson \& B. Habberjam, Trans.). Minneapolis: University of Minnesota.

Deleuze, G. (1994). Difference and repetition. New York: Columbia University Press.

Derrida, J. (1982). Margins of Philosophy. (A. Bass, Trans.). Chicago: U of Chicago Press.

Dickey, C. (2015). The Cold Rim of the World. Long Reads, March.

Dillon, B. (2011). Ruins. London: Whitechapel Gallery.

Dillon, B. (2014). Ruin Lust: Artists' fascination with ruins, from Turner to the present day. London: Tate Publishing.

Douglas, M. (1966). Purity and danger: An analysis of concepts of purity and taboo. London: Routledge \& Kegan Paul.

Edensor, T. (2005). Industrial Ruins: Spaces, Aesthetics and Materiality. London: Berg.

Eiland, H. \& Jennings, M. W. (2014). Walter Benjamin: A Critical Life. Cambridge (MA): Belknap Press.

Eshel, A. (2010). Layered Time: Ruins as Shattered Past, Ruins as Hope in Israeli and German Landscapes and Literature. In J. Hell \& A. Schőnle (Eds.), Ruins of Modernity: 133-150. Durham: Duke University Press.

Flatley, J. (2008). Affective Mapping: Melancholia and the Politics of Modernism. Cambridge MA: Harvard University Press.

Fukuyama, F. (1992). The End of History and the Last Man. New York: Free Press.

Gelman, J. (1997). Unthinkable Tenderness: Selected Poems (J. Lindgren, Trans.). Berkeley University of California Press. 
González-Ruibal, A. (2008). Time to destroy: An archaeology of supermodernity. Current Anthropology, 49(2): 247-279.

Grandin, G. (2013). Empire's Ruin: Detroit to the Amazon. In A. L. Stoler (Ed.), Imperial Debris: On Ruins and Ruination: 115-130. Durham: Duke University Press.

Gregg, M., \& Seigworth, G. (2010) (eds.) The Affect reader. Durham: Duke University Press.

Gumbrecht, H. U. (2004). Production of Presence: What Meaning Cannot Convey. Stanford: Stanford University Press.

Hell, J. (2010). Imperial Ruin Gazers, or Why Did Scipio Weep? In J. Hell \& A. Schőnle (Eds.), Ruins of Modernity: 169-192. Durham: Duke University Press.

Hell, J. \& Schőnle, A. (2010). Introduction. In J. Hell \& A. Schőnle (Eds.), Ruins of Modernity: 1-14. Durham: Duke University Press.

Hill, W. E (1915). My Wife and My Mother-in-Law. Puck 16, 11, November.

Holt, R. \& den Hond, F. (2013). Sapere Aude. Organization Studies, 34(11): 1587-1600.

Huyssen, A. (2010). Authentic Ruins: Products of Modernity. In J. Hell \& A. Schönle (Eds.), Ruins of Modernity: 17-28. Durham: Duke University Press.

Jameson, F. (2009). Valences of the Dialectic. London: Verso.

Jameson, F. (2013). The Antinomies of Realism. London: Verso.

Jameson, F. (2015). The Aesthetics of Singularity. New Left Review, 92: 101-132.

Kiefer, A. (2011). L'art survivra à ses ruines. Paris: Collège de France.

Knights, D., \& Morgan, G. (1995). Strategy under the microscope: Strategic Management and its Financial Services, Journal of Management Studies, 32(2), 191-214.

Knights, D., \& Willmott, H. (1992). Conceptualizing Leadership Processes: A study of Senior Managers in a Financial Services Company, Journal of Management Studies, 29(6), 761-782.

Knights, D., \& Willmott, H. (1999). Management lives: power and identity in work organizations. London: Sage. 
Kohn, E. (2013). How forests think: toward an anthropology beyond the human. University of California Press.

Kraus, K. 1976. In These Great Times: a Karl Kraus Reader. Montreal: Engendra Press.

Lavery, C., Dixon, D., Fearnley, C., \& Pendleton, M. (2014). The Future of Ruins: Reclaiming

Abandonment and Toxicity on Hashima Island. London: Arts and Humanities Research Council.

Linstead, S., Maréchal, G., \& Griffin, R. W. 2014. Theorizing and Researching the Dark Side of

Organization. Organization Studies, 35(2): 165-188.

Macaulay, R. (1953). Pleasure of Ruins. London: Thames and Hudson

Martin, S. (2013) 'Seven Types of Sales Manager', Harvard Business Review, September.

Merewether, C. (1997). Traces of Loss. In M. S. Roth \& C. Lyons \& C. Merewether (Eds.), Irresistible

Decay: Ruins Reclaimed 25-40. Los Angeles: Getty Research Institute.

Murray, Y. M. (2015 forthcoming). Detroit Looks Toward a Massive, Unconstitutional Blight

Condemnation: The Optics of Eminent Domain in Motor City Georgetown Journal on Poverty Law and

Policy; Loyola-LA Legal Studies Paper No. 2015-12.

Navaro-Yashin, Y. (2009). 'Affective spaces, melancholic objects: ruination and the production of anthropological knowledge'. Journal of the Royal Anthropological Institute, 15(1), 1-18.

O'Doherty, D., De Cock, C., Rehn, A., \& Ashcraft, K. (2013). New Sites/Sights: Exploring the White Spaces of Organization. Organization Studies, 34(10): 1427-1444.

Powers, R. (2011). What Does Fiction Know? Places Journal (August): 1-14

Presner, T. S. (2010). Hegel's Philosophy of World History via Sebald's Imaginary of Ruins: A Contrapuntal Critique of the "New Space" of Modernity. In J. Hell \& A. Schőnle (Eds.), Ruins of Modernity. Durham: Duke University Press.

Reeves, M. (2014). Border Work: Spatial Lives of the State in Rural Central Asia. Cornell University Press.

Roberts, M. (2006). From 'creative city'to 'no-go areas'-The expansion of the night-time economy in British town and city centres. Cities, 23(5), 331-338. 
Roth, M. F. (1997). Irresistible Decay: Ruins Reclaimed. In M. S. Roth \& C. Lyons \& C. Merewether (Eds.), Irresistible Decay: Ruins Reclaimed: 1-24. Los Angeles: Getty Research Institute.

Rowlinson, M., Hassard, J., \& Decker, S. (2014). Research strategies for organizational history: A dialogue between historical theory and organization theory. Academy of Management Review, 39(3): 250-274.

Sandberg, J., \& Alvesson, M. (2011). Ways of constructing research questions: gap-spotting or problematization?. Organization, 18(1), 23-44.

Sebald, W. G. (2001). Austerlitz. London: Hamish Hamilton.

Sebald, W. G. (2002). The Rings of Saturn. London: Vintage.

Sebald, W. G. (2004). On the Natural History of Destruction. New York: Modern Library

Simmel, G. (1958). Two Essays: The Handle and The Ruin. The Hudson Review, 11(3): 371-385.

Smith, Z. (2013). Man vs. Corpse. New York Review of Books (December 5).

Smithson, R. (1967). The Monuments of Passaic. Artforum, 7(4): 48-51.

Smithson, R. (1996). Robert Smithson: The Collected Writings. Berkeley: University of California Press.

Stewart, K. (1996). A Space at the Side of the Road. Princeton, New Jersey: Princeton University Press.

Stewart, K. (2007). Ordinary affects. Duke University Press.

Stoler, A. L. (2010). Along the Archival Grain: Epistemic Anxieties and Colonial Common Sense.

Princeton/Oxford: Princeton University Press.

Stoler, A. L. (2012). Ann Laura Stoler interviewed by E. Valentine Daniel. Public Culture, 24(3): 487-508.

Stoler, A. L. (2013). Introduction. In A. L. Stoler (Ed.), Imperial Debris: On Ruins and Ruination: 1-34.

Durham: Duke University Press.

Suddaby, R., Hardy, C., \& Huy, Q. N. (2011). Introduction to Special Topic Forum: Where are the New Theories of Organization? Academy of Management Review, 36(2): 236-246.

Taussig, M. (2012). I'm so Angry I made a Sign. Critical Inquiry, 39(1): 56-88. 
Tett, G. (2015). What Detroit can teach us all, May $1^{\text {st }}$. Financial Times. London.

http://www.ft.com/cms/s/0/16108af8-eea9-11e4-a5cd-00144feab7de.html

Waible, E. \& Herdina, P. (1997). Dictionary of Philosophical Terms Volume 2: English-German/ English-

Deutsch. Munich: De Gruyter.

Woodward, C. (2002). In Ruins. London: Vintage. 
Figure 1: a fragment of the Berlin Wall

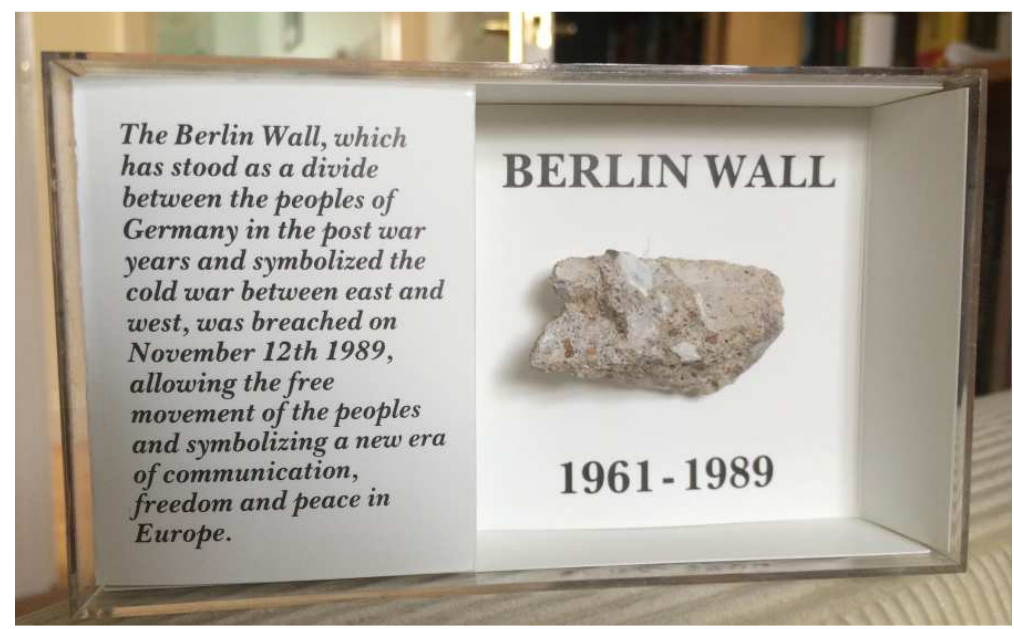


Figure 2: Abandoned railways exploration probe - multiple temporalities

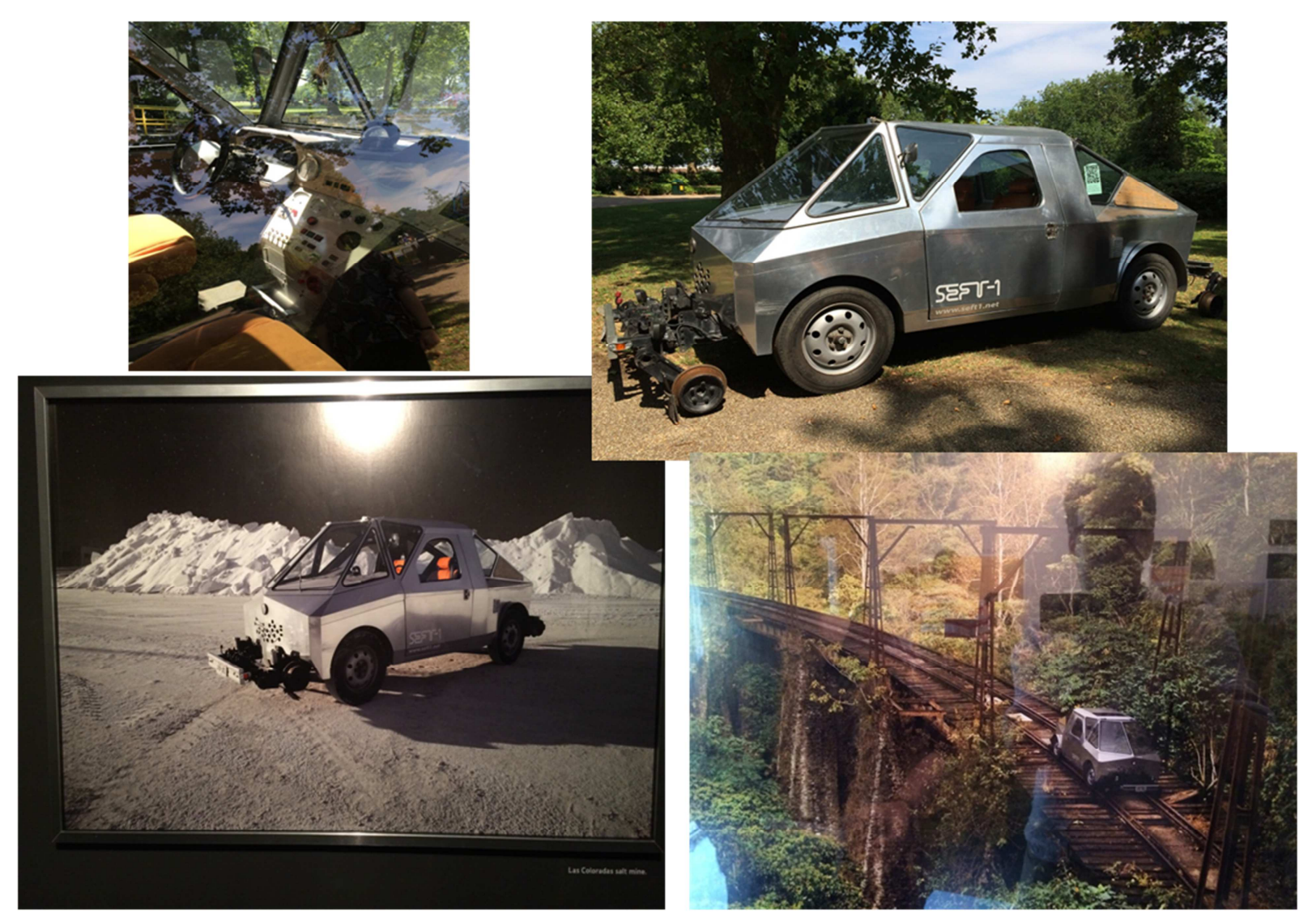


Figure 3: In Sebald's footsteps - a visit to Orford Ness
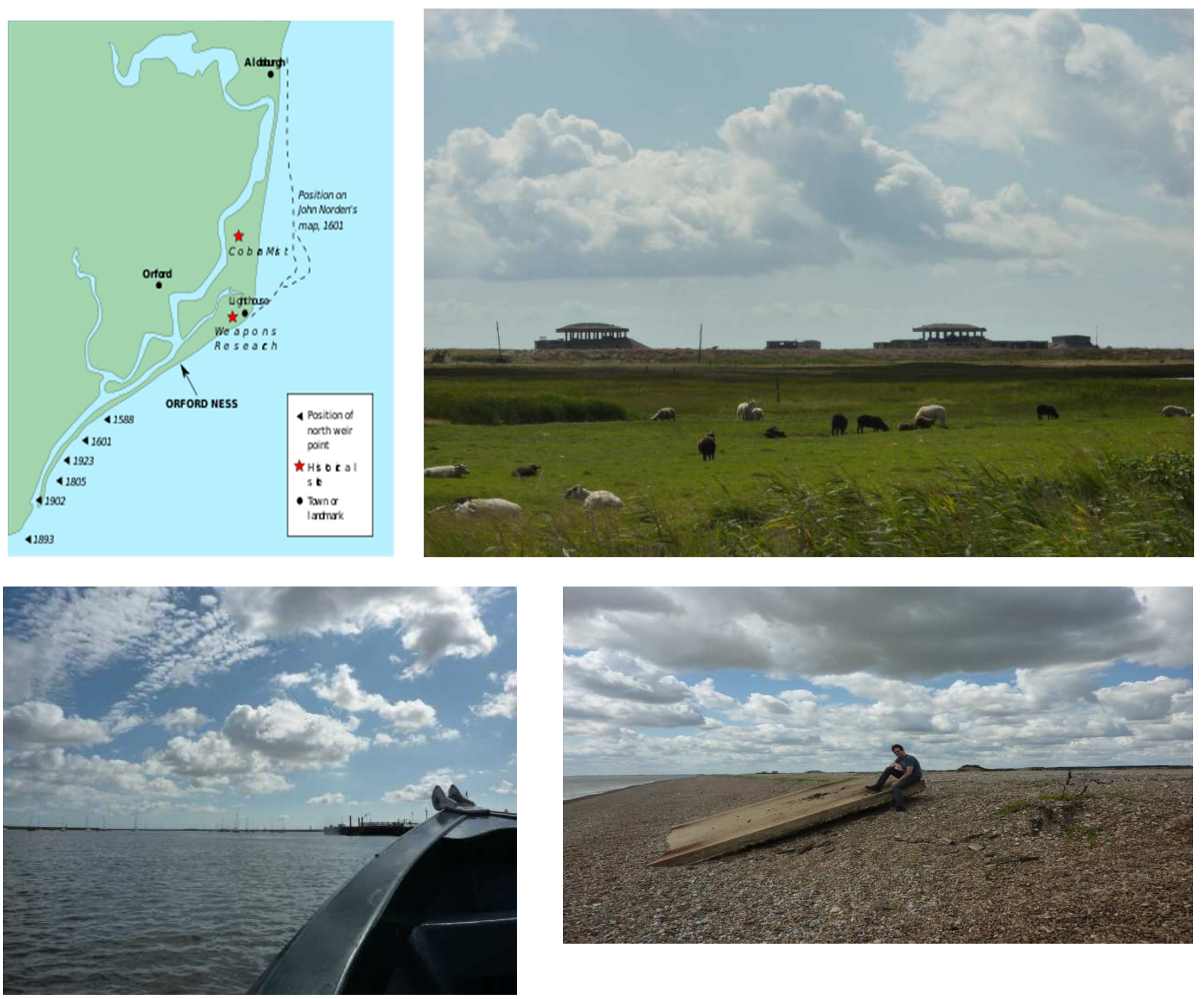
Figure 4: Haunted by absent presences
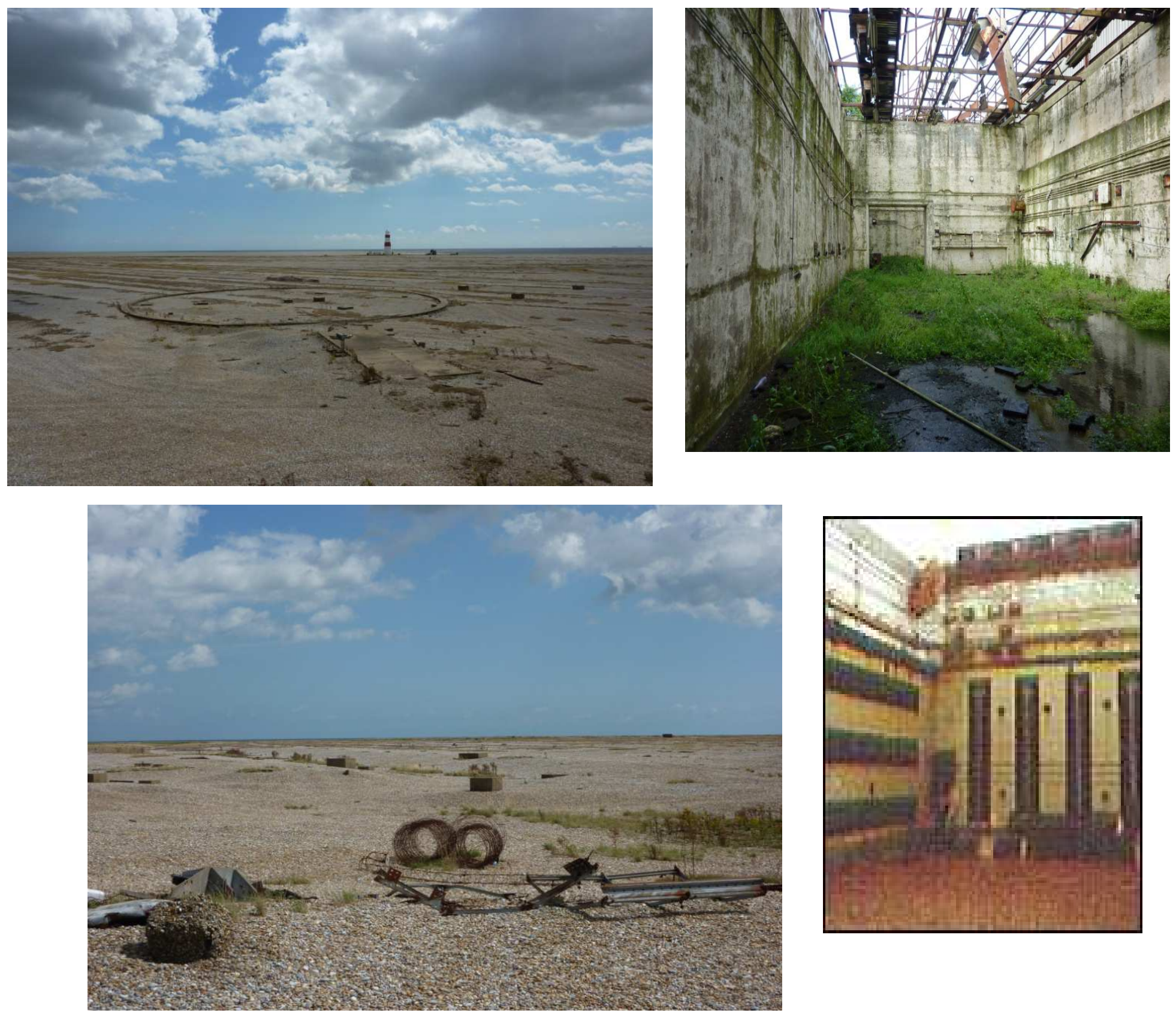